\title{
LX. On the cosmogony of moses
}

\section{J.C. Prichard Esq.}

To cite this article: J.C. Prichard Esq. (1816) LX. On the cosmogony of moses, Philosophical Magazine Series 1, 48:222, 300-300, DOI: 10.1080/14786441608637667

To link to this article: http://dx.doi.org/10.1080/14786441608637667

曲 Published online: 27 Jul 2009.

Submit your article to this journal 준

III Article views: 2

Q View related articles $₫$ 
These experiments make it evident, that metallic manganese may be united to cast iron by mixing it with a portion of charcoal; and it is probable that a sinilar effect wonld take place in the puddling, furnace. But as in these experiments with the charcoal in inixture, the iron was not decarbonated or refined enough, it cannot be positively inferred that the metallic manganese would remain alloyed with the iron during the whole process of refinement.

$$
\text { I am, \&c. }
$$

David Moshet.

LX. On the Cosmogony of Moses. Ey J. C. Prichard, Esq. To Mr. Tilloch.

Sir, - $\mathbf{Y}$ our correspondent F. E-s has vainly flattered himself with the idea of having extorted from me a confession which I have not made. Far from allowing that I never supposed him to have uttered the assertion I had imputed to him, I pointed out the particular passage in wbich that proposition is to be found, and where it is expressed in words the sense of which can only be eluded by a mere quibble.

F. E-s having at length abandoned his attack on all the points which $I$ have been anxious to defend, and contenting himself with taking up a position on wholly different gromd, I am very willing to leave him in undisturbed possession of his new quarters.

I have the honour to be, sir,

Your obedient servant,
Bristol, Oct. 14, 1816.
J. C. PRIChaRd.

LXI. Notices respecting New Books.

Transactions of the Geological Society, vol. iii: 4 to. $452 \mathrm{pp.}$

$\mathrm{W}_{\mathrm{E}}$ have great pleasure in announcing the appearance of a volume, rich in matter as well as embellishment (being accompanied with twenty-six plates and maps bound up separately), so that it cannot but prove acceptable to every geologist. The contents are as follow:

I. A Sketch of the Mineralogy of Sky. By John MacCul-

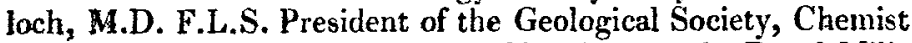
to the Ordnance, and Lecturer on Chemistry at the Royal Military Academy at Woolwich. 111 pages,-II. On the Oxyd of 